\author{
Paweł Grata \\ Department of Economic and Social History \\ Institute of History \\ University of Rzeszów \\ e-mail: pgrata@ur.edu.pl \\ ORCID: 0000-0003-2358-3475
}

\title{
THE IMPACT OF THE ECONOMIC CRISIS ON SOCIAL POLICY IN INTERWAR POLAND
}

\begin{abstract}
The aim of this paper is to determine how the economic crisis, and the ad hoc attempts made by the authorities to counteract it, affected the Polish society and, above all, to prepare a multidimensional analysis of how the crisis impacted systemic changes in the Polish social policy. The author will examine both positive changes that followed the relevant global trends and also negative changes that resulted from the developmental lag, the country's economic situation and especially the generally low involvement of the state via public funding in activities that were part of the state's social policy.

Assessment of Polish social policy during the crisis must be ambiguous. On the one hand, systemic changes in social policy introduced as a result of the economic collapse can be clearly distinguished, on the other hand, however, the severity of the crisis visibly affected many activities of state and local governments in the social sphere. These activities posed unsuccessful attempts to rescue the situation in the labour market. Additionally, an effective response to deepening poverty was missing, amendments adopted to labour legislation were disadvantageous to employees, and finally fundamental sacrifices in terms of social policy were made as the lawmakers passed the Unification Act during the crisis. Polish social policy was unable, for a number of reasons, to essentially redefine its approach to addressing the numerous social issues it had to face.

Keywords: interwar Poland, Polish social policy, the Great Depression, employment policy, social security.
\end{abstract}

\section{Background}

At the end of the 1920s the greatest economic crisis in history flooded the entire capitalist world and it shook the European and global economy in a long-lasting way. Some countries felt its consequences for as long as a decade. It was a formative experience for all people who had to live through it and its reminiscences occupied their minds for their whole lives. A short list of effects of the collapse that painfully struck the economies 


\section{Pawel Grata}

in the early 1930s included the catastrophic breakdown of production, the subsequent fall in employment and the rise in unemployment to unprecedented levels, growing poverty, a wave of bankruptcies in almost all industries, the disastrous situation in agriculture, the stock market crash, the crisis in the banking system, the unravelling of the international financial system, the disruption of world trade, budgetary difficulties of countries affected by the recession and, finally, its social consequences. A wellknown long-term effect of the Great Depression became the visible redefinition of the principles of economic policy - state interventionism and related instruments of macroeconomic influence were widely used. Due to the social effects that the economic crisis brought in its train, the social sphere would play a special role, especially since Keynesianism ascribed it a considerable potential for economic recovery and the associated improvement of the situation of millions of families affected by the crisis. After all, it is a common opinion that the Great Depression and the subsequent World War II became a decisive step on the path to building the post-1945 welfare state. The measures taken during the years of ongoing economic slump laid the foundations for the later system of the welfare state. They were enshrined in the social sphere of the American New Deal; however, Nazi Germany employed them just as extensively in the 1930s (see Łukasiewicz 1967; Morawski 2011; Nowaczewska 2009; Robbins 1937; Rothbart 2010).

Most of the capitalist countries undertook steps driven by the desire to improve the situation of their crisis-affected citizens. In expanding the instruments aimed at influencing the social sphere they changed permanently how governments impinged on the functioning of the market mechanism. Hence it is also worth examining how the economic crisis affected the social policy of interwar Poland, which had only existed for just over a decade at the time when the crises broke out. Until then Poland had been very ambitiously creating the rules for influencing the social sphere, even though the Polish state was still in the initial stage of its establishment, it was not very wealthy and its economy depended heavily on agriculture. Additionally, the occupational structure of the Polish population was not modern and, in many respects, it was unfavourable.

The aim of this paper is to determine how the economic crisis, and the ad hoc attempts made by the authorities to counteract it, affected the Polish society and, above all, to prepare a multidimensional analysis of how the crisis impacted systemic changes in the Polish social policy. The author will examine both positive changes that followed the relevant global trends and also negative changes that resulted from the developmental lag, the coun- 
try's economic situation and especially the generally low involvement of the state via public funding in activities that were part of the state's social policy.

\section{Polish social policy on the verge of the crisis}

By the late 1920s the social policy that the new proclaimed Polish state had to build from scratch looked very promising. In the first decade of its independence, Poland managed to establish a modern system of labour protection institutions. The foundations for unemployment insurance, co-financed by the state budget, were laid and associated labour market institutions established. A modern welfare law was adopted and a process intended for the unification and universalisation of social insurance was initiated. On the other hand, however, the system was still incomplete and clearly underfunded. Additionally, several aspects were simply neglected. The system of labour protection, although modern, faced numerous problems as solutions enshrined in legislation benefiting employees were not observed. The social insurance still did not cover old age and disability of workers in the former Austrian and Russian partitions, and unemployment insurance was available only to employees of establishments with more than five workers. Besides that, the framework character of legislation on social welfare and health care hindered the state and local governments from wielding real influence on both these areas (Grata 2020: 797-809).

Significantly, in all areas of social policy, financial considerations remained the primary constraint hampering their further development. In the period concerned, less than 3 percent of the state budget was appropriated for social spending. This amount did not match the real needs, even in the good economic times of the late 1920s, when no extraordinary amount of social expenditure was necessary, let alone in crisis situations. The second constraint was the above-mentioned occupational structure of the population, which was unfavourable for the development of social policy. This was a systemic hindrance and impossible to correct in the foreseeable future. Approx. 70 percent of the Polish population resided in rural areas and two-thirds of the labour force relied on agriculture for their livelihoods; however, social policy served, by definition, salaried employees not working in the agricultural industry. This fact determined the small number of beneficiaries of social welfare in Poland. By the end of the 1920s, the most widespread sickness insurance, which included family members of the insured, covered only about 15 percent of 
the Polish population, and the rates for other forms of insurance were even lower. Judging by the dramatically low spending on social welfare in rural communities and an unremitting understaffing of medical personnel there, which defined the scale of inaccessibility of health care, on the threshold of the greatest crisis in history, Polish social policy was still at the preliminary stage of its development, the more so as even most workers of non-agricultural industries were not guaranteed unemployment insurance (Grata 2021: 88-93).

\section{Social consequences of the economic crisis in Poland}

The Great Depression hit hardest the most industrialised countries with developmentally advanced economies, such as the United States and Germany. This is where the greatest declines in basic economic indicators were recorded, while the course of the depression was generally milder in less developed countries. An exception to this rule was the economic crisis and its effects in Poland. The extent of the collapse resembled that of the most industrialised countries, and the scale of the resulting economic and social problems was also similar. The reasons for this were the backward structure of the Polish economy, the widespread poverty and the crisis-induced progressive autonomisation of fundamental sectors - agriculture and the broadly defined countryside, industry and the urban economy. This resulted in rural areas, potentially the primary market, being cut off from the production of goods and services. On the other hand, the opening of the price scissors was extremely hard and unfavourable for the countryside where the income of the vast majority of inhabitants, who worked in agriculture, fell considerably, thus cutting them off from the urban market. As a result, Poland's industrial production decreased by around 46 percent in three years. Numerous industrial, commercial and banking establishments went bankrupt, state budget revenue dropped by about one-third and incomes in agriculture fell dramatically. Additionally, indebtedness rose rapidly in rural areas (see Landau, Tomaszewski 1982).

Under the circumstances, the social impact of the crisis was equally negative. There were masses of unemployed in the cities and the impoverishment of families deprived of their previous sources of livelihood was growing. People in the countryside had no money to buy basic consumer goods, there were tax executions which affected people. Finally, the minimal supply of food completed the picture of a drama that millions of Poles 
had to deal with during this time. This picture is widespread in literature and it has been reproduced in numerous memoires and recollections, but it has not been not fully explored to this day as it is not possible to fully know the true extent of the social problems involved (see Ciepielewski 1965; Pamiętniki... 1933; Pamiętniki... 1935; Makowski 1979; Wrzos 1933).

The basic issue was, of course, the common impoverishment of society. Its extent correlated with the above-mentioned factors, which directly influenced the income of the population. In cities, its primary cause remained undeniably unemployment, which in turn generated further social issues. In rural areas, where, theoretically, unemployment in the classical sense did not exist, poverty resulted from the decrease in income and the fact that people were unable to find a job in the non-agricultural economy that was deeply affected by the economic depression. Unemployment, widely recognised as the biggest social problem in Poland during the economic crisis, was for many reasons impossible to quantify precisely. Registered unemployment, although it was characterised by high growth dynamics at that time, cannot be used as a reliable indicator to assess the phenomenon. Suffice it to say that at the end of 1931, according to the data presented by the employment offices, there were 312,000 job seekers while the results of the census conducted at that time showed as many as 684,000 unemployed. Moreover, reliable and well-founded estimates prepared by independent researchers in subsequent years put the number of unemployed at over one million. Based on the existing structure of manpower utilised in non-agriculture industries, this meant an unemployment rate estimated in 1932-1934 at around 30 percent, i.e. a figure comparable to that recorded in the American labour market at the same time (in 1935 unemployment in Poland still exceeded 26 percent) (Grata 2021: 111-112).

The extent of unemployment indicated above also does not exhaust the entire problem. Apart from those who had no job at all, there was a large group of people who worked only part-time, just a few days a week. This must have had a bearing on their income and their families' standard of living too. According to official statistics, during the economic crisis as many as 30 percent of all employees worked less than 6 days a week (between 1932 and 1933 their number was even closer to 40 percent) and one in ten of those employed part-time worked only 1 to 3 days a week (Maty... 1939: 158).

In addition to rapidly rising unemployment, which grew to be a structural phenomenon, there was also a multitude of people living in the countryside who were an expendable labour force there and could leave for the cities to work in industry without impairing the agricultural economy. Un- 


\section{Pawet Grata}

derstandably, the levels of this so-called hidden (latent) unemployment were difficult to determine, since every farm could use some help, but the relevant estimates were simply alarming, bearing in mind the available opportunities to solve the problem. Suffice it to say that the Ministry of Interior estimated the size of this reserve labour force, which could leave the villages without doing any harm to the rural economy, in a document drawn up the late 1936, after the crisis had passed, to be as many as 5-6 million people. Even if we take into account the lower estimates of 2-3 million unemployed in the countryside which were made later, under better economic conditions, and were based on sound research, this figure determined that this social issue would not be solved in the foreseeable future (Drozdowski 1961: 218-219; Młodzie z... 1938: 110).

The effects of the impoverishment of society resulting from the lack of job opportunities and income were multidimensional. The economic crisis further reduced the accessibility of the already poorly-developed health care. The incidence of infectious diseases increased as did infant mortality. Millions of citizens were deprived of subsistence needs and even cases of starvation were recorded in various regions, particularly in the eastern provinces. In cities, the living and housing conditions of tens of thousands of workers, the unemployed and their families deteriorated. The number of homeless people grew, as did crime and social pathologies. In addition, the citizens saw their access to social benefits, extremely important for their social security, reduced (Grata 2021: 90).

Another aspect of social welfare that suffered from the economic crisis were workers' rights. The achievements of the workers' legislation adopted in the first years of independence were openly questioned. High unemployment rates and the spectre of job loss resulted in the employers visibly dominating in labour relations. The employees, being the weaker party, were forced into new terms and conditions of employment, sometimes incompatible with the legislation still in force. Accordingly, at the beginning of the 1930s the number of violations of working time regulations and annual leave entitlement increased progressively (in the early 1930s workers in large and mediumsized enterprises used on average five days of annual leave instead of the statutory 15 days). The extent of flawed employment of young workers, who were generally underpaid, grew too. Under the difficult labour market conditions medical boards evaluating young people as to whether they were fit for work were inclined to make decisions that were unfavourable to the applicants in terms of their health, by qualifying them for work (regardless of the applicants' actual health condition almost every evaluation of the medical board was positive out of concern for their income-earning 
chances). The employment of women saw a considerably increased number of labour regulation violations. Women carried out jobs in industrial establishments that minors and women were prohibited from doing as determined by the list of 1925 (see Inspekcja... 1929-1935; Landau, Tomaszewski 1971: 457, 624; Miedzińska 1933: 123-128).

\section{State response to the social effects of the economic crisis}

The challenges posed by the social impact of the economic crisis influenced the change of in the ways in which public authorities in virtually all the countries affected by the economic slump approached social welfare. This applied to interwar Poland too. However, the turn in Polish social policy was far from comparable to that of the Roosevelt administration, which was a model in this respect. First and foremost, it should be noted that the economic crisis and its social consequences drove the public authorities to react in an almost classic fashion, for that time, by attempting to rescue the situation, at least temporarily. Similarly to what had happened after the Great War, or during the post-stabilisation crisis resulting from the introduction of the Grabski reform, the state took steps to support the rapidly growing numbers of the unemployed and poor, acting on the assumption that emergency aid would help them survive the crisis until the imminent - as it was expected - upturn in the economy occurred. Only over time, as in other countries, systemic measures would emerge as a result of the continuing recession. In the Polish reality, these measures, although generally positive, were not entirely significant and this because of, again, fundamental considerations, directly resulting from the level of socio-economic development in Poland.

Prior to these systemic changes taking place, the authorities had already taken steps that were considered to be self-evident when economic problems arose. The increase in unemployment itself was partly cushioned by the benefits to which laid off workers were entitled under unemployment insurance and paid by the Unemployment Fund (for a period of 13 weeks). The extent of the phenomenon is well illustrated by the fact that in 1931 unemployment benefits were paid to 113,000 jobless persons, while as recently as 1928 there were only 28,000 such persons (Sprawozdanie... 1934: 40).

The further, rapid increase in unemployment and its transformation into a permanent phenomenon, combined with the assumed short duration of benefit payments, forced the public authorities to intervene directly in the relief efforts. Hence, in addition to the statutory benefits, the so-called 


\section{Pawet Grata}

special assistance for the unemployed, first introduced in the 1920s, was launched. The support provided under this instrument still proved advantageous to several tens of thousands of unemployed in 1929. The budget spent nearly 30 million Polish zlotys on special assistance in 1930 alone. The concomitant increase in spending on other welfare needs meant that the first years of the crisis saw a rapid increase in spending on social policy. In the financial year of 1931/32 the spending amounted to almost 167 million Polish zlotys, reaching the previously (and later) unimaginable share in the state budget of seven percent (Ustawa... 1924; Zamknieccie... 19231937/38; Polityka... 1935: 165-166).

With the rapid decline in tax revenues, however, it became apparent that such large-scale cash assistance could not be provided over an extended period of time. Unemployment benefits, already gradually rationed, were thus replaced by in-kind assistance. Starting in September of 1931, it was coordinated by the Prime Minister's Supreme Unemployment Committee (Naczelny Komitet do Spraw Bezrobocia), which was replaced in 1932 by the Unemployment Fund. The evolution of assistance for the unemployed, known as 'emergency aid', continued in the subsequent years and its final model did not take shape until 1936, when it was taken over by the National Civic Committee for Unemployment Assistance (Ogólnopolski Komitet Pomocy Bezrobotnym) which was supported by the Labour Fund taking various measures for the benefit of the unemployed (Ciechocińska 1965: 161-164; Naczelny... 1932: 6-12; Sprawozdanie... 1936: 34).

Apart from the support for the unemployed considered as a priority, the state took measures aimed at mitigating the social effects of the crisis. In the early stages of the crisis they were aimed at 'improving' the employment structure, by preserving the jobs of adult men providing for their families at the expense of women and minors, reducing working hours, limiting overtime or imposing an obligation on establishments that wanted to fill vacancies to hire only people registered as unemployed. However, in spite of the relevant resolution adopted by the government on 26 August 1931, these demands did not produce visible results and the labour market situation continued to deteriorate (Ciechocińska 1965: 72-73; Uchwały... 1931: 1279).

An inevitable consequence of the crisis was also the rapidly increasing number of people requiring welfare support. In this case, however, under the existing legislation, most of the tasks fell to the local governments. The state took care of the organisation and supervision of welfare activities. It would only intervene if the local governments could not handle the phenomenon on their own. Under the first guideline, the Ministry of Labour and Social Welfare (later the Ministry of Social Welfare) encouraged local 
governments to make far-reaching savings, combined with a re-adjustment of rules for providing aid, while under the second guideline, the central authorities stepped in primarily when natural disasters occurred and the local governments were unable to cope with their effects single-handedly.

The great flood of 1934 which affected vast areas of the provinces of Cracow, Lwów and Kielce, became symbolic of the nationwide relief efforts. Significantly, since the situation of the state budget worsened substantially, the National Committee for Flood Victim Assistance (Ogólnopolski Komitet Pomocy Ofiarom Powodzi), established for this purpose, ensured support. As a result, in two years only 3.4 million Polish zlotys from the state budget were allocated to the support for flood victims, while the Committee collected and spent 27 million Polish zlotys in this period (in good economic times, i.e. in 1927/28, the state spent nearly 10 million Polish zlotys on mitigating the effects of the flood of 1927 and other natural disasters) (Ogólnopolski... 1934; Zamknięcie... 1927/28: 196-197; 1934/35: 117; 1935/36: 115).

During the economic crisis the state also provided help to regions suffering from malnutrition or even famine. The problem was particularly acute in Polesie and the mountainous Boyko land, Hutsul and Pokucie region. The problem of malnutrition recurred there fairly regularly, but the volume of the assistance provided in the form of food was generally considered unsatisfactory, and the insufficient support gave rise to resentment, understandable in many cases, among national minorities living in these areas towards the Polish state (Grata 2021: 150-151).

\section{Elements for reorienting social policy}

The subsequent years of the economic crisis brought visible changes in Polish social policy. These changes were tangible, though not always unambiguously positive, and in some cases they clearly limited the scope of previously granted social rights. The recognition of unemployment as the most acute social issue and the adoption of measures as a systemic response to such a finding was the first and most important change. At the same time, the approach to social welfare started to change. Up to this point, modern solutions were introduced 'incidentally', only when critical situations emerged. From then on, they would also include broader groups of beneficiaries than before. To some extent, the economic crisis triggered the introduction of some positive modifications to labour legislation too. On the other hand, it would be far-fetched to associate the attempt to change the vectors of 


\section{Pawel Grata}

social policy with one of the symbols of the state's legislative activity during the economic crisis, i.e. the Social Insurance Act of March 1933 which was at the same time a great step towards building a modern social security system.

For reorienting social policy, changes of employment policy were by far the most important. The above-mentioned emergency measures taken to counteract unemployment did not bring about real results, because they simply could not. This is why in 1933 an initiative intended to change the situation, at least partially, including in conceptual terms, emerged. The Act of 16 March 1933 established the Labour Fund, an institution that was guaranteed extra-budgetary funds far greater than those previously available to activities intended for combating unemployment. The Labour Fund also brought a new approach to the problem. It was tasked with the organisation of public works, a symbol of the modern approach to the fight against unemployment. Public works were supposed not only to provide the unemployed with jobs, but also to advance the modernisation processes of the state through important infrastructure investments. In addition, the Labour Fund took a number of measures to activate specific groups of people deprived of work, thus diversifying its offer and adapting it to the needs of its beneficiaries. Activities undertaken by the Labour Fund included, among others: support for vocational training and provision of jobs for unemployed youth, subsidies for institutions employing unemployed white-collar workers, a campaign aimed at creating allotment gardens for people without a job, resettlement of the unemployed to carry out public works outside their place of residence, organisation of additional activities for the agricultural population within the handicrafts and cottage industry, and subsidies for chambers of agriculture to improve the management of small farms (Ustawa z dnia 16 marca... 1933: Sprawozdanie... 1938) ${ }^{1}$.

The changes in social welfare were the second major shift in emphasis in Polish social policy closely related to the economic crisis. The aforementioned drive to reduce costs due to the significantly increasing scale of needs produced paradoxically advantageous effects. These emerged primarily as part of the efforts to replace the expensive and rather negatively viewed institutional care with other forms of support. During the economic crisis the much cheaper and, at the same time, more beneficial foster care for children was given priority. As a result, within a few years around 20 percent of all children in need of care could thus grow up in families rather than in institutions. At the same time, it was emphasised that a much larger number of people required support; however, this would be in-kind support instead of monetary. With the development of out-patient health care, 
the emergence of health and care centres that combined caring, preventive and curative functions became a completely new quality in this respect (Grata 2013: 220, 228-234).

When discussing the changes in Polish social policy that took place during the economic crisis, we cannot ignore the aforementioned Social Insurance Act, commonly referred to as the Unification Act. After years of debates the act was finally adopted in 1933 and it introduced common social insurance for workers against old age, disability and death, and the related old-age and invalidity pensions, previously unavailable in the former Russian and Austrian partitions. On the other hand, however, despite its almost revolutionary nature, it can hardly be viewed as an advantageous element of the reorientation of Polish social policy taking place during the crisis. It only made up for the clear backwardness of the system. The law itself was to a large extent the effect of negative, crisis-driven circumstances and it contained many solutions that were not entirely favourable, reflecting the time period in which it was adopted. Understandably, the difficult situation of entrepreneurs and the state budget influenced the 'austerity' nature of the law and determined the contributions, which placed a greater burden on employees than previously assumed, and the low level of future benefits. Additionally, sickness benefits were reduced and agricultural workers were left out of the system. Hence it must be acknowledged that the Unification Act, without questioning its importance, was partially flawed and not entirely consistent with the solutions proposed in the 1920s. But this was due to the ongoing economic crisis (Chylak 2017: 379-394; Ustawa z dnia 28 marca... 1933).

Moreover, the Act itself was closely linked to fundamentally unfavourable to workers changes introduced to labour legislation, in force for more than a decade. On 22 March 1933, a few days before the new insurance law was passed, the Polish parliament amended the acts on working time in industry and commerce (first adopted on 18 December 1919) and on annual leave for workers employed in industry and commerce (first adopted on 16 May 1922). Under the pretence of support for crisis-stricken entrepreneurs both of these laws restricted workers' rights. As a consequence, one may say that the economic crisis negatively affected the development of Polish labour legislation, which had looked modern at the dawn of independence, but regressed in the early 1930s (Ustawa z dnia 22 marca... 1933).

The reduction in budget expenditure on social policy affirmed the clearly negative trends, deepening with the continuing crisis. In the first years of the economic collapse, its share rose to 7 percent of total spending. In 1931-1932 it decreased to 5 percent and in 1934-1935 it fell further 


\section{Pawet Grata}

to just over 3 percent and 2.7 percent respectively (Grata 2017: 20). Even though the fall resulted partly from the transfer of most of the expenditure from the budget to the Labour Fund for combating unemployment, nevertheless this confirms that the place of social issues in state policy was barely re-evaluated in the wake of the economic crisis. The more so, as it was assumed that the Labour Fund, which had become symbolic of modern social policy, would only attend to city residents and the participants of the 'urban' labour market, who constituted a small part of the Polish population, thus excluding the unemployed living in rural areas from participation in public works. The regressive trend in the financing of social welfare and public health care was clearly confirmed by the decline in expenditure that local governments made on both these areas during the economic crisis. This was particularly evident in health care, where in the mid1930s spending dropped to just 45 percent of its pre-crisis volume (in social care the corresponding figure was 54 percent in 1935-1936) (Maty... 1939: 399-400).

\section{Conclusion}

To sum up the analysis of how the economic crisis impacted the social policy of interwar Poland, it must be concluded that the assessment of the relevant processes taking place in the early 1930s is ambiguous. On the one hand, systemic changes in social policy introduced as a result of the economic collapse can be clearly distinguished, on the other hand, however, the severity of the crisis visibly affected many activities of state and local governments in the social sphere. These activities posed unsuccessful attempts to rescue the situation in the labour market. Additionally, an effective response to deepening poverty was missing, amendments adopted to labour legislation were disadvantageous to employees, and finally fundamental sacrifices in terms of social policy were made as the lawmakers passed the Unification Act during the crisis.

Hence, the conceptual advances occurring during the economic collapse did not change significantly the state involvement in social affairs. However, it could not have been otherwise, given the fact that the Polish state had modest economic potential, it was not prosperous, and neither were its citizens. Besides, the decision makers were not willing, practically up to the outbreak of WWII, to carry out fundamental changes to Polish social policy that was otherwise well-defined, including in terms of needs. In any case, these changes would had been very costly and difficult to implement. 
Hence it is only logical that the most developed Western countries, with the United States and Germany at the forefront, became the forerunners of large-scale economic interventionism, accompanied by growing significance and increased investments in the social sphere. Despite some important and tangible changes carried out during the economic crisis, Polish social policy was unable, for a number of reasons, to essentially redefine its approach to addressing the numerous social issues it had to face.

\section{N O T E}

${ }^{1}$ In the second half of the 1930s, during the summer months, the number of unemployed persons performing public works reached a total of 170,00. In 1936-1937 the annual budget of the Labour Fund for public works alone amounted to nearly 96 million Polish zlotys, while the budget of the entire Ministry of Social Welfare was only 44 million Polish zlotys.

\section{B I B L I O G R A P H Y}

Chylak, K. (2017). Ubezpieczenia spoleczne i zaopatrzenia emerytalne w II Rzeczypospolitej. Warszawa: Wydawnictwo Polskie IHOO.

Ciechocińska, M. (1965). Próby walki z bezrobociem w Polsce międzywojennej. Warszawa: Państwowe Wydawnictwo Ekonomiczne.

Ciepielewski, J. (ed). (1965). Wieś polska w latach Wielkiego Kryzysu 1929-1935. Materiały i dokumenty. Warszawa: Książka i Wiedza.

Drozdowski, M. M. (ed.). (1961). Sprawozdanie Referatu Zawodowego Wydziału Bezpieczeństwa Ministerstwa Spraw Wewnętrznych o stanie bezrobocia w Polsce. Najnowsze Dzieje Polski. Materiaty i Studia z okresu 1914-1939. Vol. 4, 218-219.

Grata, P. (2013). Polityka spoleczna Drugiej Rzeczypospolitej. Uwarunkowania instytucje - działania. Rzeszów: Wydawnictwo Uniwersytetu Rzeszowskiego.

Grata, P. (2017). At the origins of welfare state? Social expenses in the budgetary policy in the Second Polish Republic, Studia Historiae Oeconomicae 35, 726.

Grata, P. (2020). Polityka społeczna Niepodległej Rzeczypospolitej - budowa i ewolucja systemu. Prace Historyczne Uniwersytetu Jagiellońskiego 4, 797809.

Grata, P. (2021). The Origins of the Welfare State. Polish Social Policy in the Period 1918-1939, Berlin: Peter Lang.

Inspekcja Pracy w 1929 roku (1930). Warszawa: Ministerstwo Pracy i Opieki Społecznej.

Inspekcja Pracy w 1930 roku (1931). Warszawa: Ministerstwo Pracy i Opieki Społecznej. 


\section{Pawet Grata}

Inspekcja Pracy w 1931 roku (1932). Warszawa: Ministerstwo Pracy i Opieki Społecznej.

Inspekcja Pracy w 1932 roku (1933). Warszawa: Ministerstwo Pracy i Opieki Społecznej.

Inspekcja Pracy w 1933 roku (1934). Warszawa: Ministerstwo Pracy i Opieki Społecznej.

Inspekcja Pracy w 1934 roku (1935). Warszawa: Ministerstwo Pracy i Opieki Społecznej.

Inspekcja Pracy w 1935 roku (1936). Warszawa: Ministerstwo Pracy i Opieki Społecznej.

Landau, Z. and Tomaszewski, J. (1982). Gospodarka Polski miedzywojennej 19181939. T. III. Wielki Kryzys 1930-1935. Warszawa: Książka i Wiedza.

Landau, Z. and Tomaszewski, J. (1971). Robotnicy przemysłowi w Polsce. Materialne warunki bytu 1918-1939, Warszawa: Książka i Wiedza.

Łukasiewicz, J. (1967). Krach na gietdzie. Zarys historii kryzysów ekonomicznych. Warszawa: Wiedza Powszechna.

Makowski, E. (ed). (1979). Pracy nam dajcie! Wspomnienia Wielkopolan z lat 1919-1939. Poznań: Wydawnictwo Poznańskie.

Maty Rocznik Statystyczny. (1935). Warszawa: Główny Urząd Statystyczny.

Miedzińska, J. (1933). Polityka państwa wobec młodzieży pracującej. Praca i Opieka Społeczna 2, 123-128.

Młodzież siega po prace (1938). Warszawa: Instytut Spraw Społecznych.

Morawski, W. (2011). Kronika kryzysów gospodarczych. Warszawa: Diffin.

Naczelny Komitet do Spraw Bezrobocia przy Prezesie Rady Ministrów. Sprawozdanie z działalności w okresie 5 IX - 31 XII 1931 r. (1932). Warszawa.

Nowaczewska, R. (2009). Dobroczynna Ameryka. Walka ze skutkami Wielkiego Kryzysu w latach 1929-193\%. Warszawa: Wydawnictwo Uniwersytetu Rzeszowskiego.

Ogólnopolski Komitet Pomocy Ofiarom Powodzi i akcja pomocy powodzianom (1934). In Central Archiv of Modern Records in Warsaw, Prezydium Rady Ministrów. Akta grupowe 1932-1939, file no. 143-2.

Pamiętniki bezrobotnych (1933). Warszawa: Instytut Gospodarstwa Społecznego.

Pamiętniki chłopów (1935). Warszawa: Instytut Gospodarstwa Społecznego.

Polityka społeczna państwa polskiego 1918-1935 (1935). Warszawa: Ministerstwo Opieki Społecznej.

Robbins, L. (1937). Wielkie przesilenie gospodarcze. Kraków: Towarzystwo Ekonomiczne.

Rothbart, M. (2010). Wielki kryzys w Ameryce. Warszawa: Instytut Ludwiga von Misesa.

Sprawozdanie z działalności Funduszu Bezrobocia 1933 (1934). Warszawa: Fundusz Bezrobocia. 
The Impact of the Economic Crisis on Social Policy in Interwar Poland

Sprawozdanie z działalności Funduszu Pracy za okres od 1 kwietnia 1934 r. do 31 marca 1935 r. (1936). Warszawa: Fundusz Pracy.

Sprawozdanie z działalności Funduszu Pracy za okres od 1 kwietnia 1937 r. do 31 marca 1938 r. (1938). Warszawa: Fundusz Pracy.

Uchwały Rady Ministrów w sprawie złagodzenia skutków bezrobocia w okresie zimowym 1931-1932 r. (1931). Polska Gospodarcza 35, 1279.

Ustawa z dnia 18 lipca 1924 r. o zabezpieczeniu na wypadek bezrobocia (1924). Dziennik Ustaw nr 67, poz. 650.

Ustawa z dnia 16 marca 1933 r. o Funduszu Pracy (1933). Dziennik Ustaw nr 22, poz. 163.

Ustawa z dnia 22 marca 1933 r. w sprawie zmian w ustawie z dnia 18 grudnia 1919 r. o czasie pracy w przemyśle i handlu (1933). Dziennik Ustaw nr 27, poz. 227.

Ustawa z dnia 22 marca 1933 r. w sprawie zmian w ustawie z dnia 16 marca 1933 r. w sprawie zmian w ustawie z dnia 16 maja 1922 r. o urlopach dla pracowników, zatrudnionych w przemyśle i handlu (1933). Dziennik Ustaw nr 27, poz. 228.

Ustawa z dnia 28 marca 1933 r. o ubezpieczeniu społecznym (1933). Dziennik Ustaw nr 51, poz. 396.

Wrzos, K. (1933). Oko w oko z kryzysem. Reportaż z podróży po Polsce. Warszawa: F. Hoesick.

Zamknięcie rachunków państwowych za lata 1923-1936/37 (1928-1939). Warszawa: Ministerstwo Skarbu. 